Emir. J. Agric. Sci. 2004. 18 (1): 01-10

http://www.cfa.uaeu.ac.ae/research/ejas.html

\title{
Effect of cropping arrangements and rainfall on the performance of okra (Abelmoschus esculentus (L.) Moench) in Bauchi State, Nigeria
}

\author{
B. I. Ahmed, S. R. Yusuf, A. A. Garba and S. Mustapha \\ Crop Production Programme - School of Agriculture \\ Abubakar Tafawa Balewa University, Bauchi, Nigeria
}

\begin{abstract}
Field experiments were conducted at the Teaching and Research Farm of Abubakar Tafawa Balewa University, Bauchi, Nigeria during the farming seasons of 1997-1999. The objective of the experiments was to establish the effects of cropping arrangements and rainfall on the performance of two varieties of okra plant (Indian long white and short local varieties) in terms of flower and fruit initiation as well as height and yield. Twenty four experimental plots were demarcated and arranged into eight treatment plots. Each treatment was replicated three times and the size of each of the plots was $4.2 \mathrm{~m} \times 3.6 \mathrm{~m}$. Results of the experiments clearly indicated that when the two varieties were independently grown with cotton, cowpea and groundnut at a ratio of one to one (1:1) per plot, performance of the plant especially in terms of height, flower, fruit initiation and yield was greatly enhanced. It is therefore, recommended that farmers should under rainfall condition practice growing okra particularly the two varieties tested (ILWV \& SLV) with other plants such as cotton, cowpea or groundnut in order to increase the growth, development and yield of okra.
\end{abstract}

Keywords: Cropping arrangements, okra, rainfall and performance.

الثر تدلل المحاصلل ولاملار عل الداءمحصط البامياف ولاية بيبي نيجيربا

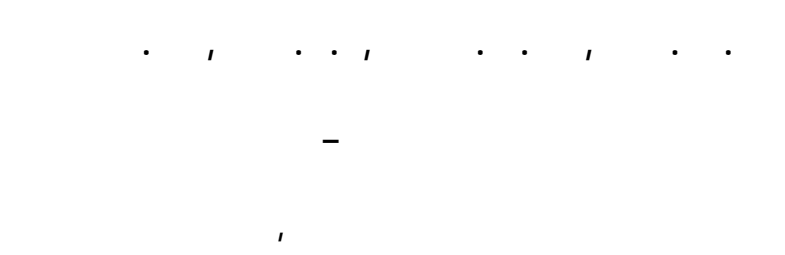

الملخص: لجريت تجربة حقلية خلال الموسم الزراعي 1999/1997 في مزرعة التدريب والبحوث, جلمعة البوبكر تفاوا باليوا, بيجي, نيجيريا. الهذف من الدرلسة هو لتبيت الثر تدلخل المحاصل والاطلار على اداء نوعين من محصول البلميا (النوع الهندي الابيض الطويل والمحلي القصير) من نلحية الازهار, بدء الاثمار,

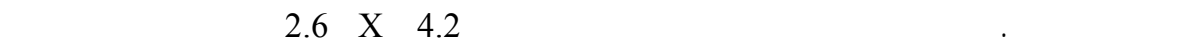

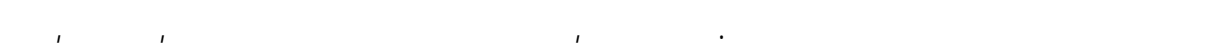
الاثمار والانتاج قد زاد بشكل واضح عند زراعة النوعين(النوع الهندي الابيض الطول والمحلي الق صير)

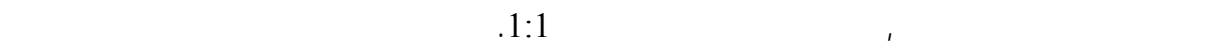

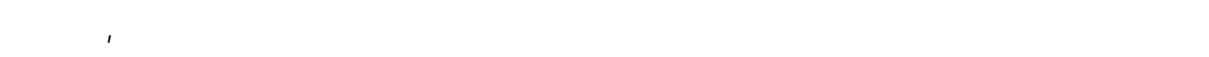
والنتاج محصول البلميا 


\section{Introduction}

Okra (Abelmoschus esculentus (L.) Moench) is an important vegetable crop grown both in the tropics and subtropics and is a native of Africa (BSADP, 1995). In Nigeria, the crop is grown both during the rainy season as well as in the dry season under irrigation (Ayuk, 1997).

Okra is a good source of protein, vitamin and mineral elements needed for the development and maintenance of human body. The immature fruits are eaten either fresh or cooked by boiling or frying. The fruit may also be dried and milled to powder for use as flavoring (Tindall, 1986). The fruit is also important in neutralizing the acidic substances produced in the course of digestion of meat and other foods (Attifield, 1998). Similarly, Tindall (1986) reported that fruits of okra are rich in calcium and iron, matured fruits are used in the replacement of plasma. Mucilage from the stem and root is used for clearing of cane juice during the preparation of high quality jaggery (Chaudhury, personal communication). The fruit also lend itself well to freezing and canning products (Dike, 1983). Foliage of okra plants are known to provide good sources of fodder for livestock (BOSADP, 1998). According to Karakoltiside and Constantinides (1975), the seeds are utilized potentially as a good source of oil in the tropics. In United States of America and Holland, the interest in Okra is from the standpoint of its gum and fibre (Tindall, 1986) and its medicinal properties (Grewal et al., 1972.).

Inspite of high nutritional values and usefulness of okra plant to man and animals, the crop is reported to be attacked by large number of insect pests both in the tropical and sub-tropical regions of the world (Hill and Walter, 1988). According to Hill (1987) there are 9 major and 30 minor insect pests attacking okra in different parts of Africa. These insects are known to feed on the crop and at the same time transmit various diseases to the crop (Kumar 1984). According to Perrin (1977) one of the greatest limiting factors in attempting to increase the productivity of farmers is the wide range of insect pests attacking crops in farm and to obtain a meaningful yield, these insect pests must be controlled. Control of insect pests is the management of pest population usually to reduce pest numbers at least to an equilibrium level so that their effects on mankind are less harmful, more crop yield is produced and hence a better quality of life for man and his animals can be achieved (David, 1995). Information about crop protection techniques and methods is generally scarce in many tropical and subtropical countries, especially for rural communities, small farmers, field workers and local extension staff. This information is often over-simplified and biased towards commercial interest, therefore tending to give only the positive aspect of pesticide usage. Information about environmental hazard and health risks associated with pesticide usage is usually unavailable to farmers. It is for these reasons that it was considered unwise and unhealthy to always depend on agrochemicals as means of controlling insect pests and improving the performance of plants in the field. From the afore-mentioned problems of pesticide usage in the control of insect pests, the use of cropping arrangement has been considered as one of the options for the 
reduction of insect pests infestation. Multiple cropping is reported to have numerous advantages among which are the regulation of insect pest population and improvement of growth and yield (Umaru et al., 1998).

Although, okra farmers have not adopted the practice of intercropping okra with other crops frequently as a means of improving the growth and yield of the plant, an attempt was made in this study to investigate the effects of rainfall and intercropping or mixing/planting okra plant with some selected crops such as cotton, cowpea and groundnut on the performance of the plant in terms the growth and yield in Bauchi State, Nigeria.

\section{Materials and Methods}

Field experiments were conducted in a Randomized Complete Block Design (RCBD) under rainy season for three consecutive seasons 1997-1999, to establish the effects of cropping arrangements on the growth and yield of okra in Bauchi. Two varieties of okra, Indian long white and short local varieties (ILWV \& SLV) were intercropped with cotton, cowpea and groundnut at a ratio of one to one (1:1) per plot. Furthermore, the two okra varieties were each planted sole on different plots as control in an attempt to evaluate the performance of the crop. The size of each of the experimental plot was $4.2 \mathrm{~m} \times 3.6 \mathrm{~m}$ separated by a border of $1 \mathrm{~m}$ path and $2 \mathrm{~m}$ between each replication. Total numbers of treatments were eight and each was replicated three times. During each planting season, the land was first cleared, ploughed and harrowed twice. Seeds of the two varieties of okra were soaked in water for 24 hours before they were sown. This was done in order to hasten germination (Tindall, 1986). The okra seeds were sown $30 \mathrm{~cm}$ within rows and $60 \mathrm{~cm}$ between rows. The two okra varieties were first planted independently as sole crops to serve as control while groundnut, cotton, and cowpea were each intercropped differently with the two varieties of okra at a ratio of one is to one (1:1) per plot. At 15 days after germination, okra seedlings were thinned to one seedling per stand and missing stands if any were replaced with seedlings sown on the same date so as to ensure uniform plant population in all the plots. At 20 and 60 days after planting (DAP) NPK and Urea fertilizers were applied, respectively to all the okra plants each at the rate of $50 \mathrm{~kg} / \mathrm{ha}$ as recommended by George (1985). Other agronomical practices such as weeding and proper management measures were strictly observed.

Five plants from two middle rows of each of the 24 plots were randomly selected and tagged for recording observations. Parameters assessed on these plants included: (1) height of those plants during vegetative and reproductive growth stages, and (2) number of days to flower and fruit initiation.

Furthermore, harvesting of fresh fruits started when they were due and continued until the crops started drying and no more fruits were produced on them. The five randomly selected plants used for assessing the above mentioned parameters were also utilized for yield assessment. Fresh fruits of those plants were picked once in a week and the weights of harvested fruits were recorded and summed up at the end of the crop's life. In addition, number of fruits per plant was also recorded.

Data obtained in all the cases were subjected to analysis of variance and significantly $(\mathrm{P}<0.05 \%)$ different means were separated using Student NewmanKeul Test (SNK). 


\section{Results}

Table 1 is the meteorological data of the study area obtained during the rainy seasons of 1997 - 1999. The results clearly showed that in 1997, lowest and highest quantities of rainfall of $27.2 \mathrm{~mm}$ and $207.1 \mathrm{~mm}$ were obtained during the months of April and August, respectively. Similarly in 1998, a lowest quantity of rainfall of about $28.3 \mathrm{~mm}$ with a relative humidity of $4.9 \%$ was observed in the month of April. Equally during the same year in question, highest rainfall of $243.6 \mathrm{~mm}$ with relative humidity of $36.5 \%$ was observed in the month of August. However, the 1999 meteorological data showed that highest rainfall of $273.4 \mathrm{~mm}$ and lowest rainfall of $0.5 \mathrm{~mm}$ were received during the months of August and March, respectively

Effects of cropping arrangement and rainfall on the height of okra plant during its vegetative and flowering/ fruiting growth stages of 1997-1999 trials are presented in Tables 2 and 3. During these periods, individual cropping arrangements significantly influenced height of the two okra varieties. Minimum heights of $31.6 \mathrm{~cm}$ and $49.6 \mathrm{~cm}$ were recorded in 1997 during the vegetative and flowering/ fruiting growth stage of SLV, respectively. Furthermore, maximum heights of $16.4 \mathrm{~cm}$ and $225.0 \mathrm{~cm}$ were recorded in 1999 during the vegetative and flowering/ fruiting growth stages of the SLV and ILWV, respectively. The data in Tables 2 and 3 also show that height of all the intercrop treatments of ILWV were significantly higher than the ones sown as sole crop throughout the years (1997-
1999). In other words, intercrop treatments of ILWV and SLV had higher plant heights and better yield than those sown as sole crop. However, within the intercrop mixtures, ILWV mixtures were better than their corresponding mixtures in SLV.

Number of days taken by the two varieties of okra plant to start flowering during the rainy seasons of 1997-1999 is presented in Table 4. Similarly, data on number of days taken by the two okra varieties to start fruiting during the period in question (1997-1999) is presented in Table 5. All the available data shows that cropping arrangements significantly $(\mathrm{P}<0.05)$ influence the performance of the two varieties of okra (SLV and ILWV) in terms of flower and fruit initiation. Longest and shortest numbers of days spent by okra plants to start flower initiation were recorded in ILWV sown as sole crop (95.3) and ILWV intercropped with cowpea (40.7) during the planting seasons of 1999 as shown in Table 4, respectively. Similarly, shortest and longest periods spent by okra plants to start fruit initiation were recorded in the intercrop treatments of ILWV with cowpea (45.7) and ILWV sown as sole crop (104.6) during the farming seasons of 1997 and 1999, respectively (Table 5). Generally, number of days spent by individual okra plant to start either flowering or fruiting was longer in okra sole crop treatments when compared with intercrop treatments. Furthermore, even within the okra intercrop treatment, mixture of ILWV took longer period before they started to produce flower and fruits as compared to their corresponding mixtures in SLV. 
Emir. J. Agric. Sci. 2004. 18 (1): 01-10

http://www.cfa.uaeu.ac.ae/research/ejas.html

Table 1. Meteorological data of the study area for 1997-1999.

\begin{tabular}{|c|c|c|c|c|c|c|c|c|c|}
\hline \multirow[t]{2}{*}{ Month } & \multicolumn{2}{|c|}{1997} & \multirow[b]{2}{*}{$\begin{array}{c}\text { R. H. } \\
(\%)\end{array}$} & \multicolumn{2}{|c|}{1998} & \multirow[b]{2}{*}{$\begin{array}{c}\text { R. H. } \\
(\%)\end{array}$} & \multicolumn{2}{|c|}{1999} & \multirow[b]{2}{*}{$\begin{array}{c}\text { R. H } \\
(\%)\end{array}$} \\
\hline & $\begin{array}{c}\text { Rainfall } \\
(\mathrm{mm})\end{array}$ & $\begin{array}{c}\text { Temp. } \\
\left({ }^{\circ} \mathrm{C}\right)\end{array}$ & & $\begin{array}{c}\text { Rainfall } \\
(\mathrm{mm})\end{array}$ & $\begin{array}{c}\text { Temp. } \\
\left({ }^{\circ} \mathrm{C}\right)\end{array}$ & & $\begin{array}{l}\text { Rainfall } \\
(\mathrm{mm})\end{array}$ & $\begin{array}{c}\text { Temp. } \\
\left({ }^{\circ} \mathrm{C}\right)\end{array}$ & \\
\hline Jan. & 0.0 & 30.2 & 20 & 0.0 & 31.0 & 33.5 & 0.0 & 29.8 & 30.2 \\
\hline Feb. & 0.0 & 30.4 & 30 & 0.0 & 24.1 & 34.7 & 0.0 & 29.9 & 34.6 \\
\hline Mar. & 0.0 & 38.3 & 20 & 0.0 & 24.5 & 8.5 & 0.5 & 35.2 & 33.3 \\
\hline Apr. & 27.2 & 38.9 & 38 & 28.3 & 38.2 & 4.9 & 23.0 & 36.8 & 51.0 \\
\hline May & 104.8 & 36.2 & 57 & 106.4 & 37.3 & 36.5 & 120.0 & 38.2 & 48.6 \\
\hline Jun. & 197.0 & 36.5 & 65 & 220.4 & 36.3 & 32.7 & 225.0 & 39.1 & 50.8 \\
\hline Jul. & 123.1 & 31.3 & 74 & 239.2 & 30.4 & 31.5 & 454.3 & 33.2 & 70.2 \\
\hline Aug. & 207.1 & 30.2 & 80 & 243.6 & 30.2 & 30.5 & 273.4 & 34.6 & 73.5 \\
\hline Sept. & 202.8 & 30.9 & 78 & 205.2 & 31.6 & 30.7 & 265.1 & 32.7 & 57.9 \\
\hline Oct. & 19.4 & 29.2 & 61 & 26.6 & 30.3 & 32.6 & 151.1 & 30.8 & 40.0 \\
\hline Nov. & 0.0 & 28.3 & 37 & 0.0 & 28.4 & 32.2 & 2.7 & 29.6 & 25.4 \\
\hline Dec. & 0.0 & 28.2 & 33 & 0.0 & 25.2 & 32.8 & 0.0 & 28.6 & 21.2 \\
\hline
\end{tabular}

Sources: 1997 and 1998 from Federal Meteorological Office, Bauchi, and 1999 from A.T.B.U., Bauchi, Nigeria. Meteorological Centre, Bauchi.

Table 2. Height of okra Plants during the vegetative growth stage of the plant at Bauchi, Nigeria.

\begin{tabular}{lccc}
\hline \multirow{2}{*}{ Treatments } & \multicolumn{3}{c}{$\begin{array}{c}\text { Height of Plant (cm) under various } \\
\text { treatments during the planting season of }\end{array}$} \\
\cline { 2 - 4 } & $\mathbf{1 9 9 7}$ & $\mathbf{1 9 9 8}$ & $\mathbf{1 9 9 9}$ \\
\hline SLV & 31.6 & 42.2 & 53.2 \\
ILWV & 45.1 & 55.2 & 69.7 \\
SLV + Cotton & 40.9 & 43.6 & 55.0 \\
ILWV+ Groundnut & 51.9 & 80.1 & 89.7 \\
SLV + Cowpea & 45.0 & 44.4 & 54.8 \\
ILWV + Cotton & 47.7 & 82.6 & 92.7 \\
SLV + Groundnut & 39.9 & 44.1 & 54.7 \\
ILWV + Cowpea & 78.1 & 94.3 & 116.4 \\
SNK (P<0.05) & 7.0 & 11.9 & 11.0 \\
\hline
\end{tabular}

SLV = Short local variety; ILWV = Indian Long white variety; SNK = Student Newman-Keul Test 
B. I. Ahmed, et al.

Table 3. Height of okra plants $(\mathrm{cm})$ during the flowering/fruiting growth stages of the plant at Bauchi, Nigeria

\begin{tabular}{lccc}
\hline \multirow{2}{*}{ Treatments } & \multicolumn{3}{c}{$\begin{array}{c}\text { Height of Plant }(\mathbf{c m}) \text { under various } \\
\text { treatments during the planting season of }\end{array}$} \\
\cline { 2 - 4 } & $\mathbf{1 9 9 7}$ & $\mathbf{1 9 9 8}$ & $\mathbf{1 9 9 9}$ \\
\hline SLV & 49.6 & 53.1 & 66.7 \\
ILWV & 64.9 & 94.2 & 96.1 \\
SLV + Cotton & 80.0 & 96.2 & 98.5 \\
ILWV+ Groundnut & 116.4 & 179.2 & 186.0 \\
SLV + Cowpea & 94.6 & 101.1 & 106.5 \\
ILWV + Cotton & 126.6 & 174.3 & 186.5 \\
SLV + Groundnut & 90.9 & 97.3 & 99.3 \\
ILWV + Cowpea & 145.8 & 201.4 & 225.0 \\
SNK (P<0.05) & 21.7 & 9.7 & 12.8 \\
\hline
\end{tabular}

$\mathrm{SLV}=$ Short local variety, ILWV= Indian Long white variety, SNK = Student Newman-Keul Test

Table 4. Number of days taken by individual okra plants to flower under various treatments during the rainy seasons of 1997-1999 at Bauchi, Nigeria.

\begin{tabular}{lccc}
\hline \multirow{2}{*}{ Treatments } & \multicolumn{3}{c}{$\begin{array}{c}\text { Number of days to flower initiation } \\
\text { during the rainy season of }\end{array}$} \\
\cline { 2 - 4 } & $\mathbf{1 9 9 7}$ & $\mathbf{1 9 9 8}$ & $\mathbf{1 9 9 9}$ \\
\hline SLV & 64.3 & 75.5 & 83.3 \\
ILWV & 65.3 & 92.4 & 95.3 \\
SLV + Cotton & 53.1 & 65.1 & 72.3 \\
ILWV+ Groundnut & 52.3 & 84.0 & 71.2 \\
SLV + Cowpea & 51.7 & 64.9 & 71.2 \\
ILWV + Cotton & 50.5 & 68.9 & 69.8 \\
SLV + Groundnut & 57.0 & 66.1 & 76.1 \\
ILWV + Cowpea & 40.7 & 66.2 & 68.5 \\
SNK (P<0.05) & 7.0 & 3.9 & 12.7 \\
\hline
\end{tabular}

$\mathrm{SLV}=$ Short local variety, ILWV= Indian Long white variety, SNK = Student

Newman-Keul Test

Effects of cropping arrangements and rainfall on the yield of two varieties of okra (SLV and ILWV) during the farming seasons of 1997 to 1999 are presented in Table 6. The individual cropping arrangements significantly influenced yield in kilogram per hectare during the experimentation period. Furthermore, yield obtained in okra intercropped treatments was significantly higher $(\mathrm{P}<0.05)$ than the okra sole crop treatments. Equally, yield obtained during the rainy season of 1997 was lower than the yield of okra obtained in 1998 and 1999. However, maximum and minimum quantities of okra yield were obtained in ILWV sown as intercrop with cowpea (5311.4) and SLV sown as sole crop (450.3) during the farming seasons of 1999 and 1997, respectively. The result also showed that no significant differences were observed between ILWV and SLV sown as sole crop treatments throughout the experimentation periods. 
Emir. J. Agric. Sci. 2004. 18 (1): 01-10

http://www.cfa.uaeu.ac.ae/research/ejas.html

Table 5. Number of days taken by individual okra plants to fruit under various treatments during the rainy seasons of 1997-1999 at Bauchi, Nigeria.

\begin{tabular}{lccc}
\hline \multirow{2}{*}{ Treatments } & \multicolumn{3}{c}{$\begin{array}{c}\text { Number of days to flower initiation during } \\
\text { the rainy season of }\end{array}$} \\
\cline { 2 - 4 } & $\mathbf{1 9 9 7}$ & $\mathbf{1 9 9 8}$ & $\mathbf{1 9 9 9}$ \\
\hline SLV & 71.7 & 79.2 & 90.7 \\
ILWV & 70.0 & 97.4 & 104.5 \\
SLV + Cotton & 61.9 & 68.1 & 75.8 \\
ILWV + Groundnut & 58.7 & 92.0 & 88.7 \\
SLV + Cowpea & 59.3 & 70.9 & 74.6 \\
ILWV + Cotton & 60.2 & 73.9 & 82.0 \\
SLV + Groundnut & 61.9 & 70.1 & 77.2 \\
ILWV + Cowpea & 45.7 & 72.2 & 87.6 \\
SNK (P<0.05) & 7.9 & 4.0 & 4.0 \\
\hline SLV = Short local variety, ILWV= Indian Long & white variety, SNK = Student \\
Newman-Keul Test & \multicolumn{4}{l}{}
\end{tabular}

Table 6. Effects of different treatments on the mixed cropping arrangements with cotton, cowpea and groundnut on the growth and yield of okra during the rainy season of 1997-1999 at Bauchi, Nigeria.

\begin{tabular}{|c|c|c|c|}
\hline \multirow[t]{2}{*}{ Treatments } & \multicolumn{3}{|c|}{$\begin{array}{l}\text { Yield of Okra obtained during the rainy } \\
\text { season of }\end{array}$} \\
\hline & 1997 & 1998 & 1999 \\
\hline SLV & 450.3 & 560.2 & 618.8 \\
\hline ILWV & 489.5 & 595.6 & 695.5 \\
\hline SLV + Cotton & 1742.2 & 1855.0 & 1996.3 \\
\hline ILWV+ Groundnut & 3143.1 & 4142.2 & 4847.4 \\
\hline SLV + Cowpea & 2015.2 & 2225.9 & 3259.6 \\
\hline ILWV + Cotton & 3850.1 & 4356.9 & 5180.0 \\
\hline SLV + Groundnut & 2312.8 & 3111.8 & 4105.1 \\
\hline ILWV + Cowpea & 3962.1 & 4825.2 & 5311.4 \\
\hline SNK $(\mathrm{P}<0.05)$ & 151.2 & 184.6 & 572.5 \\
\hline
\end{tabular}

SLV $=$ Short local variety, ILWV $=$ Indian Long white variety, SNK = Student Newman-Keul Test 


\section{Discussion}

Results of the present research investigations have indicated the importance of cropping arrangements on the growth, development and yield of okra. This is because heights of the two varieties of okra at vegetative and flowering/ fruiting growth stages of the plant were much higher in okra intercropped plots throughout the experimentation periods. Furthermore, the number of days taken by individual okra plants to flower and to some extent bear fruits was found to be shorter in okra mixed plots when compared to okra sole cropped plots. The possible reason for the good performance of okra plant under intercropping arrangement is probably because of the low population trend of okra pests in the intercropped plots while the possible reasons for the poor performance of okra plant in sole cropped plots may be attributed to the high population of okra pests. (Ahmed et al., 2004). The results therefore confirm the superiority and importance of rainfall and intercropping arrangements in agriculture (Ahmed, 2001). Although, not much has yet been published on this aspect of okra plant but results of the present investigation is in agreement with the findings of Anene (1997) and Ahmed (2001) which independently investigated the effect of cropping arrangement on number of okra leaves and reported that cropping arrangement significantly increased the photosynthetic activity of okra leaves. The result is also in agreement with the findings of Taylor (1973) which reported that growing okra plant under sole cropping condition lead to serious defoliation and subsequent yield reduction. Similar observations were made in 1990 at India (Chaudhury, personal communication).
Generally, performance of the two varieties in terms of plant height and number of days to flowering and fruit bearing was poorer in 1997 than in 1998 and 1999. The reasons for this marked variation is because amount of rainfall received in Bauchi State in 1997 was lower than that of 1998 and 1999 and hence was not enough for good performance of okra plant (Table 1). This investigation therefore confirmed the earlier findings of BSADP (1995) which reported that lack of enough rainfall is detrimental to the successful performance of okra in Northern Nigeria.

Similarly, results of the present investigation show that yield obtained during the farming seasons of 1997 to 1999 corresponded with the performance of okra plant in terms of its growth and development (height as well as number of days to start flowering and fruit bearing) under various cropping arrangements. This is so because more yield was obtained in okra intercropped plots compared to the okra sole crop plots throughout the experimentation period. Results of the present investigation are positively correlated with the statements of Shri et al. (1998) which earlier reported that the purpose of any sound pest management by intercropping is not only to reduce pest population but equally reduce loss of crop yield and quality. Okigbo and Greenland (1998) concluded that farmers in Africa practice intercropping because it gives higher total yields and greater returns than the same crop grown under monocropping system. In conclusion, result of the present finding is a clear indication that farmers are more assured of at least some yield of the crop they are interested in when they practice different cropping arrangements. Farmers are more assured of high returns from practicing different cropping arrangements than practicing sole 
Emir. J. Agric. Sci. 2004. 18 (1): 01-10

http://www.cfa.uaeu.ac.ae/research/ejas.html

cropping. It is therefore, recommend that farmers should practice growing okra particularly the two varieties tested (ILWV \& SLV) with cotton, cowpea or

\section{References}

Ahmed, B. I. 2001. Cropping Arrangement for the Management of Podagrica spp (Coleoptera: Chrysomelidae) on Okra (Abelmoschus esculentus (L.) Moench) in Bauchi State, Nigeria. Unpublished Ph.D. thesis, Abubakar Tafawa Balewa University, Bauchi 105 pp.

Ahmed, B. I., I. Onu, B. M. Hamidu and J. A. Ogidi. 2004. Intercropping okra (Abelmoschus esculentus (L.) Moench) with some selected crop for the control of Podagrica spp. (Coleoptera: Chrysomelidae) in Bauchi State, Nigeria, Nigerian Journal of Entomology 21: 1-10.

Anene, C. 1997. Effect of Attack by Flea Beetles, Podagrica spp. on seed yield of two okra cultivars at Zaria. Nigerian Journal of Entomology 8: 95-98.

Attifield, H. D. 1998. Vegetable Gardening in Western Nigeria. Unity Press, Ibadan Nigeria 29 pp.

Ayuk, E. 1997. Comparative Efficacy of Three Selected Insecticides and Some Plant Products. Unpublished B. Tech. Thesis, Abubakar Tafawa Balewa University, Bauchi, Nigeria 37, pp.

BOSADP. $198 . \quad$ Cropping Recommendations. Borno State Agricultural Development Programme, Annual Report 76 pp.

groundnut in order to increase the growth, development and yield of okra.

BSADP. 1995. Survey Report of Insect Pests and Diseases of Irrigated Crops Grown in Fadama Areas of Bauchi State, Bauchi State Agricultural Development Programme, Annual Report 16 pp.

David, D. 1995. Integrated Pest Management. Chapman and Hall Ltd, London 356 pp.

Dike, M. C. 1983. Insect Pest Associated with Okra and Kenaf in Zaria Area of Nigeria. Unpublished MSc Thesis, ABU, Zaria, Nigeria 167pp.

George, F. (1985). Response of Okra (Abelmoschus esculentus (L.) Moench) to Fertilizer. FertilizerRresearch, 8(3): 287-301.

Grewal, B. S., Nandpuri, K. S. and Kumar, J. C. 1972. Effects of Dates of Sowing, Picking of Green Pods on Seed Production of Okra. Punjab Horticultural Journal 112: 245-248.

Hill, D. S. 1987. Agricultural insect pests of the tropics and their control. Cambridge University Press, Cambridge, London, pp 46.

Hill, D. S. and J. M. Walter. 1988. Pests and Diseases of Tropical Crops. Field Handbook, London Scientists and Technical/Book, Longman Group Ltd, UK.

Karakoltisides, P. A. and S. M. Constantides. 1975. Okra seed: a new 
protein source. Journal of Agriculture and Food Chemistry 23:1204-1207.

Kumar, R. 1984. Insect Pest Control with Special Reference to African Agriculture. Edward Arnold Publishers Ltd, London, 186 pp.

Okigbo, B. N. and D. J. Greenland. 1998 . Intercropping System in Tropical Africa. Journal Publishers limited, London, pp267.

Perrin, R. M. 1977. Pest Management in multiple cropping Systems. Agroecosystem 3:93-110.

Shri, R. J., M. P. Gupta and B. D. Patils. 1998. Pest Management in fodder cowpea (Vigna unguiculata Walp) through mixed and intercropping in
India. Tropical Pest Management 35(4):345-347.

Steel, R. C. and T. H. Torrie. 1981. Principles and Procedures of Statistics. Macmillian Press New York, 450pp.

Taylor, T. A. 1973. Insects associated with okra (Abelmoschus esculentus (L) Moench) in Nigeria. Nigerian Agricultural Journal 1:108-112.

Tindall, H. D. 1986. Vegetables in Tropics. Macmillian Press, London, pp.533.

Umaru, A. B., M. C. Dike, K. I. Nwosu, S. M. Misari and G. O. Olaniyan. 1998. Effects of millet/groundnut cropping patterns on aphids population and rosette incidence. ESN Occasional Publications 31:171-181. 